Наряду с этим, установленный нами характерный для ВРВГиН высокий уровень продукции противовоспалительного IL-4, отмечаемого в различных возрастных группах обследованных детей, также следует считать прогностически неблагоприятным фактором, поскольку известно, что IL-4 подавляет образование остеокластов и является потенциальным ингибитором костной резорбции [4].

Таким образом, показана патогенетическая роль и диагностическая значимость изученных цитокинов (IL-4, IL-6, IL-18 и MCP-1) у детей с врожденной расщелиной верхней губы и неба, выраженность которых может быть критерием степени нарушения процесса ремоделирования костной ткани, что необходимо учитывать при проведении хирургического лечения у данной категории детей.

\section{Литература}

Ешиев А.М., Дарбишев Э.П., Давыдова А.К. Частота и причины рождаемости детей с врожденными расщелинами по Южному региону Кыргызстана // Молодой ученый. - 2014. — №21. - C. 39-41.

Игнатьева О.В. Врожденные расщелины верхней губы и неба у детей в Чувашской Республике //Современные проблемы науки и образования 2013. - №3. - С.181

Колесникова Н. В., Кондратьева Е. И. и др. Возрастные и половые особенности некоторых цитокинов крови здоровых детей // Кубанский научный медицинский вестник. - 2017. -№ 6 (129). - C. 68-72.

Нестерова И. В., Клещенко Е. И., Чудилова Г. А., Смерчинская Т. В., Сапун О. И., Ломтатидзе Л. В., Сторожук С. В.,Роменская В. А. Особенности цитокинового профиля здоровых новорожденных // Мат. XVI Межд. конгресса по реабилитации в медицине и иммунореабилитации // Аллергология и иммунология. - 2011. - Т. 12. № 1. - С. 133.

Симбирцев А. С. Цитокины - классификация и биологические функции // Цитокины и воспаление. - 2004. - Т. 3.№ 2. - С. 16-22.

Митропанова М. Н., Гайворонская Т. В., Любомирская Е. О. Цитокины крови у детей с врожденными расщелинами губы и неба.// Кубанский научный медицинский вестник., 2016., №4 (169), С.79-81

Супиев Т.К., Мамедов Ад.А.,Негаметзянов Н.Г. Врожденная расщелина верхней губы и неба (этиология, патогенез, вопросы медико-социальной реабилитации)// Монография, Алма-Аты, 2013, $238 \mathrm{c}$.

Celikoglu M, Buyuk SK, Sekerci AE, Ucar FI, Cantekin K Three-dimensional evaluation of the pharyngeal airway volumes in patients affected by unilateral cleft lip and palate//Am J Orthod Dentofacial Orthop. 2014;145(6):780-6.

Lopes de Rezende Barbosa G, Pimenta LA, Pretti H, Golden BA, Roberts J, Drake AF Difference in maxillary sinus volumes of patients with cleft lip and palate// Int J Pediatr Otorhinolaryngol. 2014;78(12):2234-6.

\title{
РАСПРОСТРАНЕННОСТЬ ГЕПАТИТА Е НА СЕВЕРО-ВОСТОЧНОЙ ЧАСТИ РОССИИ (НА ПРИМЕРЕ РЕСПУБЛИКИ САХА (ЯКУТИЯ))
}

\section{DOI: $10.31618 /$ ESU.2413-9335.2019.1.65.259 \\ ${ }^{1}$ Семенов С.И., ${ }^{2}$ Кузин С.Н., ${ }^{3}$ Писарева М.М., ${ }^{4,5}$ Степанов К.М., ${ }^{3}$ Комиссаров А.Б., ${ }^{3}$ Фадеев А.В., ${ }^{3}$ Егорова А.А., ${ }^{1}$ Платонов Ф.А., ${ }^{5}$ Румянцева Т.Д.}

${ }^{1}$ ФГАОУ ВО «Северо-Восточный федеральный университет им.М.К. Аммосова», Медииинский институт, г.Якутск

${ }^{2}$ ГБУЗ МО МОНИКИ им. М.Ф. Владимирского, г.Москва

${ }^{3}$ ФББУ «НИИ гриппа» Минздрава России, г.Санкт-Петербург

${ }^{4}$ ФБНУ Якутский научный цุентр комплексных медицинских проблем, г.Якутск ${ }^{5}$ ФБОУ ВО «Якутская ГСХА», г. Якутск

\section{АННОТАЦИЯ}

Создавшиеся неблагополучная эпидемиологическая ситуация в республике по всем этиологическим формам вирусных гепатитов, в том числе гепатита Е, в настоящее время указывает на необходимость изучения вируса гепатита Е, значение диких и домашних животных в передаче инфекции человеку.

По результатам серологических, молекулярно-биологических исследований выявлена высокая заболеваемость и инфицированность населения республики всеми известными вирусами гепатита. Также обнаружена повышенная циркуляция в арктической зоне России такого вируса гепатита как Е, ранее считавшегося тропической инфекцией.

Дальнейшее изучение данной проблемы позволило бы определение степени инфицированности населения известными и редко встречающимися вирусами гепатитов и их биологической опасности для популяции.

\section{ANNOTATION}

The unfavorable epidemiological situation in the country in all etiological forms of viral hepatitis, including hepatitis E, currently indicates the need to study the hepatitis E virus, the importance of wild and domestic animals in transmitting infection to humans. 
According to the results of serological, molecular biological studies revealed a high incidence and infection of the population of the republic with all known hepatitis viruses. Also found is an increased circulation in the Arctic zone of Russia of such a hepatitis virus as E, previously considered a tropical infection.

Further study of this problem would allow the determination of the degree of infection of the population with known and rarely occurring hepatitis viruses and their biological danger to the population.

Ключевые слова: HEV-инфекцией, хронический гепатит B, C, генотип, a-HEV.

Key words: HEV infection, chronic hepatitis B, C, genotype, a-HEV.

Введение. Гепатит Е относится к группе пероральных гепатитов и также представляет важную проблему здравоохранения стран всего мира и по некоторым оценкам одна треть населения мира инфицирована HEV-инфекцией [1] Исследования показывают повсеместное распространение вирусных гепатитов. Во многих странах Европы выявляемость серологических маркеров у доноров колеблется от 1,3\% в Италии до $52 \%$ во Франции, а в группах риска - у фермеров, охотников - этот диапазон варьирует от $1,3 \%$ до $52 \%[2,3]$. Традиционно считалось, что источником инфекции гепатита Е является больной с острой формой гепатита и преимущественно проявляется среди населения тропических, субтропических стран в виде вспышки острого гепатита $[4,5,6]$. Исследования последних лет показали, что вирусный гепатит $\mathrm{E}$ не только антропонозное заболевание, как ранее считалось, но и может быть зооантропонозной [7]. Причем, генотипы 1 и 2 вызывают заболевание у человека, а гентипы 3, 4 у различных диких и домашних животных (свиней, коров, лошадей, оленей, собак, уток) $[8,9,10,11,12]$. Сходство штаммов гепатита Е, выделенных у морских свинок, из сточных вод и у больного гепатитом Е составляло 93-100\% [13]. В литературе имеются сведения о заболевании острым гепатитом Е после употребления недостаточно термически приготовленного мяса оленя и кабана [14]. У больных с хроническим вирусным гепатитом любой этиологии суперинфицирование вирусом гепатита Е может вызвать острую печеночную недостаточность или прогрессирование хронического гепатита до стадии цирроза печени [15]. Часто HEV-инфекция встречается у пациентов с иммуносупрессией, у которых возможно задержка или отсутствие выраженного гуморального иммунного ответа на инфекцию. Россия не относится к эндемичным регионам в отношении гепатита Е, особенно ее северные территории. Исходя из того, что создалась неблагополучная эпидемиологическая ситуация в республике по всем этиологическим формам вирусных гепатитов, в том числе гепатита Е, в настоящее время созрела необходимость изучения вируса гепатита Е, значение диких и домашних животных в передаче инфекции человеку.

Методы и материалы. Нами проведены исследования по широте распространения маркеров вирусного гепатита Е среди населения одного из северных регионов России - Якутии. В течение 2015 года с целью определения широты распространения маркеров вирусного гепатита Е серологические (ИФА) и молекулярнобиологические (ПЦР) исследования проведены у
148 человек из разных районов республики. Методом ИФА исследования проводили на наличие a-HEV-IgG у 148 человек. В Таттинском районе обследованы 29 человек, в Усть-Алданском районе - 35. Население данных районов занята скотоводством, и основной продукт питания из животного сырья, т.е. мясо крупного рогатого скота (говядина). Из Среднеколымского района, где основным занятием населения является оленеводство и основной продукт питания оленина, исследовано всего сывороток крови у 12 человек. Обследованы больные хроническими гепатитами В и С в количестве 13 человек и 59 условно-здоровых - сотрудники дома инвалидов и престарелых.

Методом ИФА исследования проводили на наличие HBsAg, a-HBsAg (мЕд/мл), a-HBcсуммарные, a-HBc IgM, a-HBeAg, a-HBe IgG, aHDV, a-HDV-IgM, a-HCV, спектр CORE, NS3, NS4, NS5, a-HEV-IgG. Для детекции маркеров вирусных гепатитов использовали тест-системы «Гепаскан HBsAg» и «Гепаскрин» производства ЗАО «Биосервис», г. Москва, «Вектогеп D - антителастрип», производства ЗАО «Вектор-Бест», г. Новосибирск, «Anti-HBc EIA» Cobas Core, Хоффманн Ла Рош (Швейцария). Количественное определение анти-HBs проводили с использованием иммуноферментной тест-системы «anti-HBs Quant EIA II Roche» на автоматическом анализаторе Cobas Core II, фирмы «Hoffmann La Roche» (Швейцария). Методом ПЦР выделяли РНК $\mathrm{HCV}$-количественный с последующим генотипированием $\mathrm{HCV}$, ДНК HBVколичественный, PHК HDV-качественный.

Результаты. Анализ заболеваемости ВГ (вирусными гепатитами) по данным серологических исследований выявил высокую интенсивности течения эпидемического процесса среди населения Республики Саха (Якутия). Анализ представленных исследований показал, что среди населения республики имеет место высокая доля серопозитивных лиц по всем вирусным гепатитам с максимальными показателями гепатита С в группе условно-здоровых лиц (23,2\%), гепатита В $(20,2 \%)$, гепатита Е (21,2\%). Настораживает высокое инфицирование $\mathrm{HBsAg-позитивных} \mathrm{лиц} \mathrm{маркерами}$ вируса гепатита D (30\%). Сообщается о существовании большого количества генетических вариаций изолятов HEV. В настоящее время признаны четыре основные генотипы HEV: генотипы 1 и 2, которые характерны при эпидемических вспышках в человеческом сообществе неиндустриальных стран, а генотипы 3 и 4 - вызывают заболевание среди диких и домашних животных (зоонозные) в развивающихся 
и развитых странах. Причем генотипы 3 и 4 вируса E, выделенные от свиней, оленей, пятнистого мангустами, овец и кроликов, генетически отличались [6]. Учитывая повсеместное распространение вируса гепатита Е, возникновение вспышек заболеваемости среди различных групп населения, расположенных вдоль водоемов, где находятся различные хозяйства по разведению домашних животных (свинокомплексы, фермы и т.д.) нами проведено исследование широты распространения маркеров вирусного гепатита Е среди населения различных районов республики, отличающихся видом животноводства

Республика Саха (Якутия) - обширная территория, с большой протяженностью с севера на юг, что определяет наличие существенных климато-географических особенностей различных ее регионов. Значительная часть территории РС (Я) лежит в зоне вечной мерзлоты. В связи с этим эндемичный для тропических стран вирусный гепатит E не подлежал тестированию больных вирусным гепатитом и при мониторинговых исследованиях. Плотность населения и его этнический состав различается в районах РС (Я), что во многом определяет особенности эпидемического процесса инфекционных заболеваний и, в частности, вирусных гепатитов с различным механизмом передачи возбудителей. Условно территория Республики Саха (Якутия) разделена на три зоны: арктическую, сельскохозяйственную и промышленную. При этом арктические улусы характеризуются, в первую очередь, следующими климато-географическими особенностями: расположены севернее 65 градуса с.ш., отличаются суровым климатом и сравнительно низким уровнем социальноэкономического развития. Кроме того, в районах арктической зоны проживают, как правило, малочисленные народности (эвены, чукчи, юкагиры и др.). Плотность населения в этой зоне весьма невелика. Основная сельскохозяйственная деятельность в арктической зоне - оленеводство. Из этой зоны в данной публикации представлены Среднеколымский и Оленекский районы.
Основной продукт питания населения этих районов - мясо северных диких и домашних оленей. В этих районах широко развита выделка меховых изделий и обработка шкур оленей и других животных. Для сельскохозяйственной группы улусов наиболее отличительными признаками являются существенное преобладание сельского населения, занимающееся скотоводством (крупный рогатый скот, коневодство, свиноводство), сравнительно низкий объем промышленной продукции, наибольшие посевные площади. Из этой группы районов обследовано на маркеры вирусного гепатита Е население Усть-Алданского и Таттинского районов, как наиболее густонаселенных и с более развитым сельским хозяйством. Для промышленной группы характерны следующие признаки: сосредоточение городского населения, высокий объем промышленной продукции, относительно высокий уровень среднемесячной зарплаты и розничного товарооборота, высокий объем перевозки грузов, слабое развитие агропромышленной инфраструктуры. В данном исследовании представлены результаты обследования сотрудников дома престарелых г. Якутска.

Широта распространения вируса гепатита E среди населения различных районов показана на рисунке 1. Необходимо отметить, что показатели широты распространения маркеров вируса гепатита $\mathrm{E}$ по четырем районам сильно не отличаются. Общим для этих четырех районов является высокая частота обнаружения а-HEV IgG. Так среди взрослого населения города Якутска этот маркер выявлен в 23,1\% случаев, Таттинского, Усть-Алданского, Среднеколымского районов $20,0 \%, \quad 19,4 \%, \quad 18,2 \%$ случаев соответственно. Необходимо отметить отчетливое снижение частоты обнаружения a-HEV IgG у здорового населения Оленекского района. Так среди 86 обследованных в п. Харыйалаах Оленекского района, где в основном проживают оленеводы и их семьи, a-HEV IgG в сыворотке крови обнаружены лишь у 4 человек, что составило $4,65 \%$.

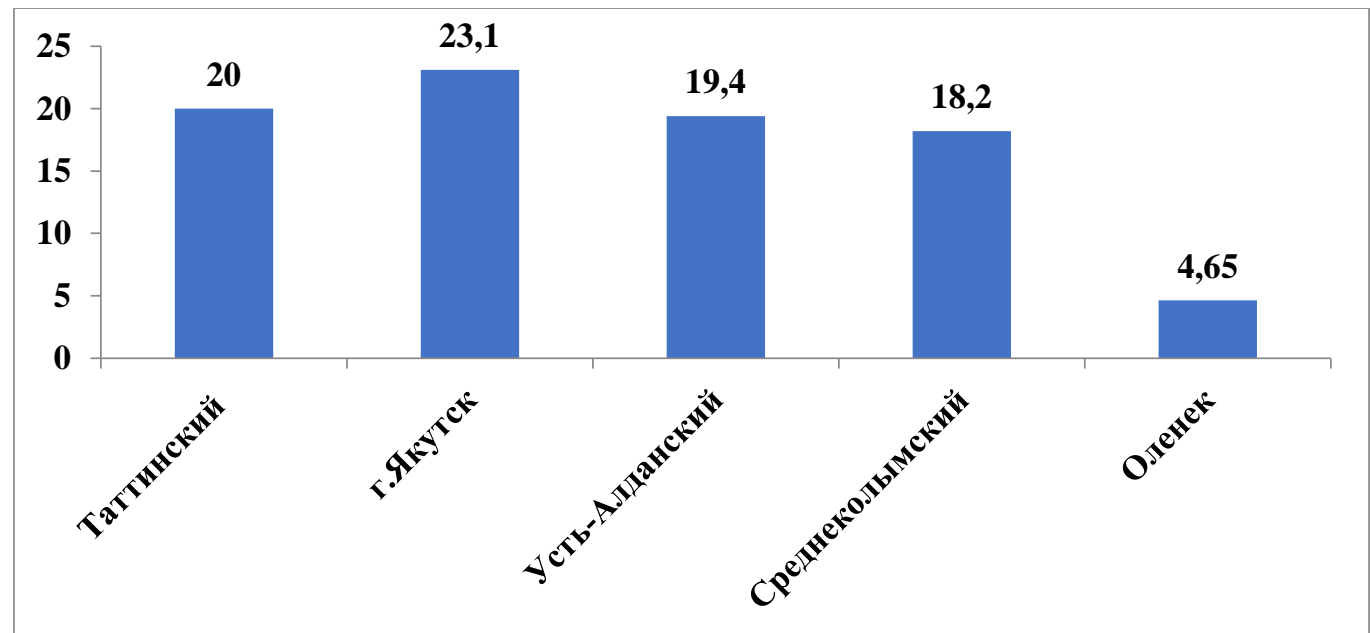

Рисунок 1. Широта распространение маркера вируса гепатита E( a-HEV IgG) среди населения различных районов Республики Саха (Якутия), показатели в \%. 
Полученные данные свидетельствуют о широком распространении вируса гепатита Е среди населения республики не зависимо от видов хозяйствования.

С целью изучения источника инфекции были проанализированы результаты обнаружения маркеров вируса гепатита Е среди населения, занимающегося скотоводством и оленеводством. Среди населения скотоводческих районов маркеры вирусного гепатита Е (a-HEV IgG) выявлены у $21,8 \%$ обследованных, среди оленеводческих районов - у 16,6\%.

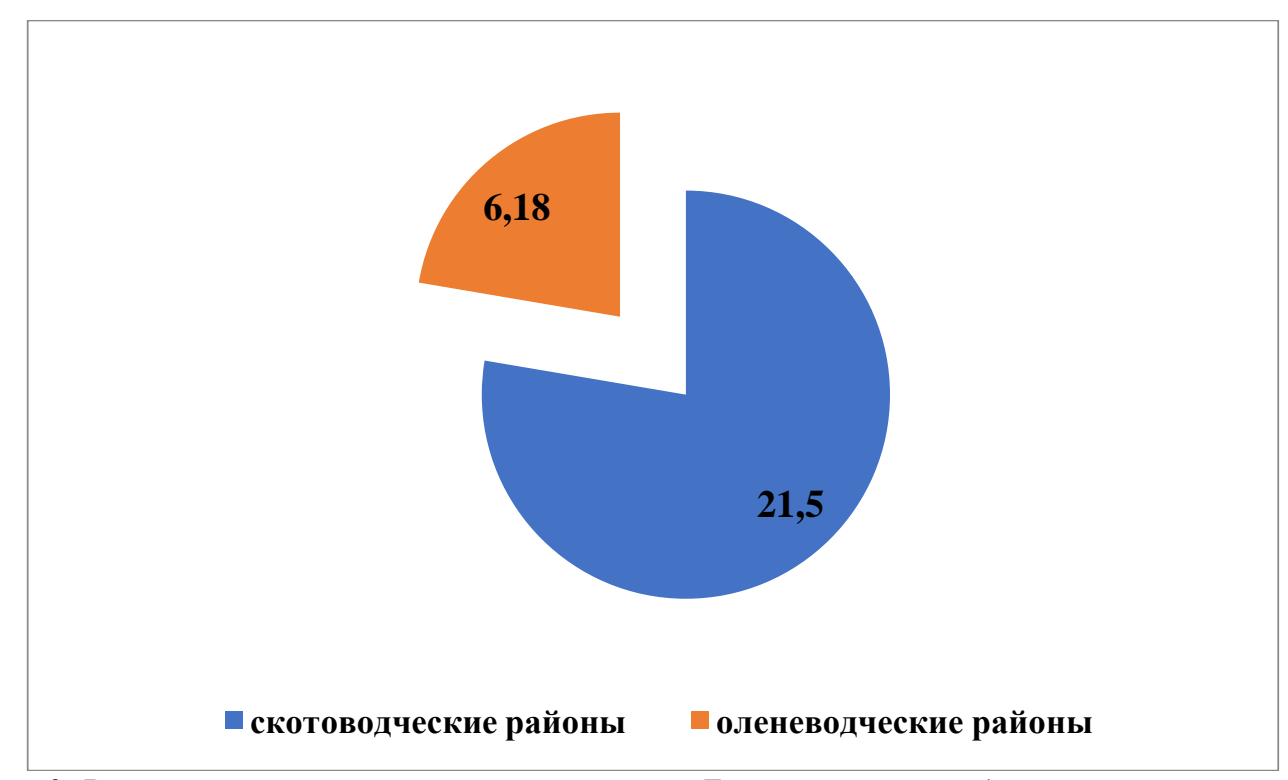

Рисунок 2. Распространенность маркера гепатита E-a-HEV I gG среди районов различного вида хозяйствования (оленеводство, скотоводство), показатели в \%.

Наши исследования показали высокую циркуляцию вируса Е среди условно-здоровых и больных вирусным гепатитом В и $\mathrm{C}-21,2 \%$ и 22,4\% соответственно. Однако наличие антител к вирусу гепатита не позволяет судить об уровне инфицированности населения, так как антитела могут сохраняться пожизненно у реконвалесцентов после перенесенного острой формы вирусного гепатита или антитела могут не сформироваться у лиц с иммуносупрессией. Для оценки истинной инфицированности нами были проведены дополнительные исследования по оценке частоты выявления ДНК вируса В (HBV), РНК вируса С (HCV) среди серопозитивных лиц. Суммарные результаты ИФА и ПЦР исследований среди 148 обследуемых представлены в таблице 1.

Таблица 1

ОБНАРУЖЕНИЕ ОСНОВНЫХ СЕРОЛОГИЧЕСКИХ МАРКЕРОВ ВИРУСОВ ГЕПАТИТОВ В, С, D И Е И ДНК, РНК ВИРУСОВ СРЕДИ БОЛЬНЫХ ХРОНИЧЕСКИМ ГЕПАТИТОМ РАЗЛИЧНОЙ ЭТИОЛОГИИ И УСЛОВНО ЗДОРОВЫХ ЛИЦ (\%).

\begin{tabular}{|c|c|c|c|c|c|c|}
\hline $\begin{array}{c}\text { Контингент } \\
\text { исследуемых }\end{array}$ & HBsAg & ДНК HBV & a-HCV & РНК HCV & $\begin{array}{c}\text { a-HDV из } \\
\text { числа } \\
\text { HBsAg (+) }\end{array}$ & a-HEV IgG \\
\hline $\begin{array}{c}\text { Условно } \\
\text { здоровые (n- } \\
\text { 99) }\end{array}$ & 20,2 & 70,0 & 23,2 & 69,3 & 30,0 & 21,2 \\
\hline $\begin{array}{c}\text { Больные } \\
\text { ХВГ (n-49) }\end{array}$ & 12,2 & 50,0 & 85,7 & 71,4 & 33,3 & 22,4 \\
\hline
\end{tabular}

Был проведен анализ полученных результатов с целью определения инфицированности населения республики лишь только вирусом гепатита Е. Обнаружение до 70\% ДНК НВV и $69,3 \%$ РНК HCV у серопозитивных условно-здоровых обследуемых свидетельствует о высокой активности вирусной Ви С-инфекции в исследуемой популяции. Полученные результаты свидетельствуют о том, что не смотря на различные пути передачи инфекции, лишь в $37,5 \%$ случаев встречается гепатит Е как моноинфекция. В соответствии с рисунком 4 наиболее часто, почти в половине случаев (42,6\%), вирус гепатита Е ассоциирован с парентеральным вирусом гепатита $\mathrm{C}$, а с другими вирусами в менее значительной доле - с вирусом гепатита В в $9,1 \%$, двумя вирусами В и С в $9,1 \%$ случаев. 


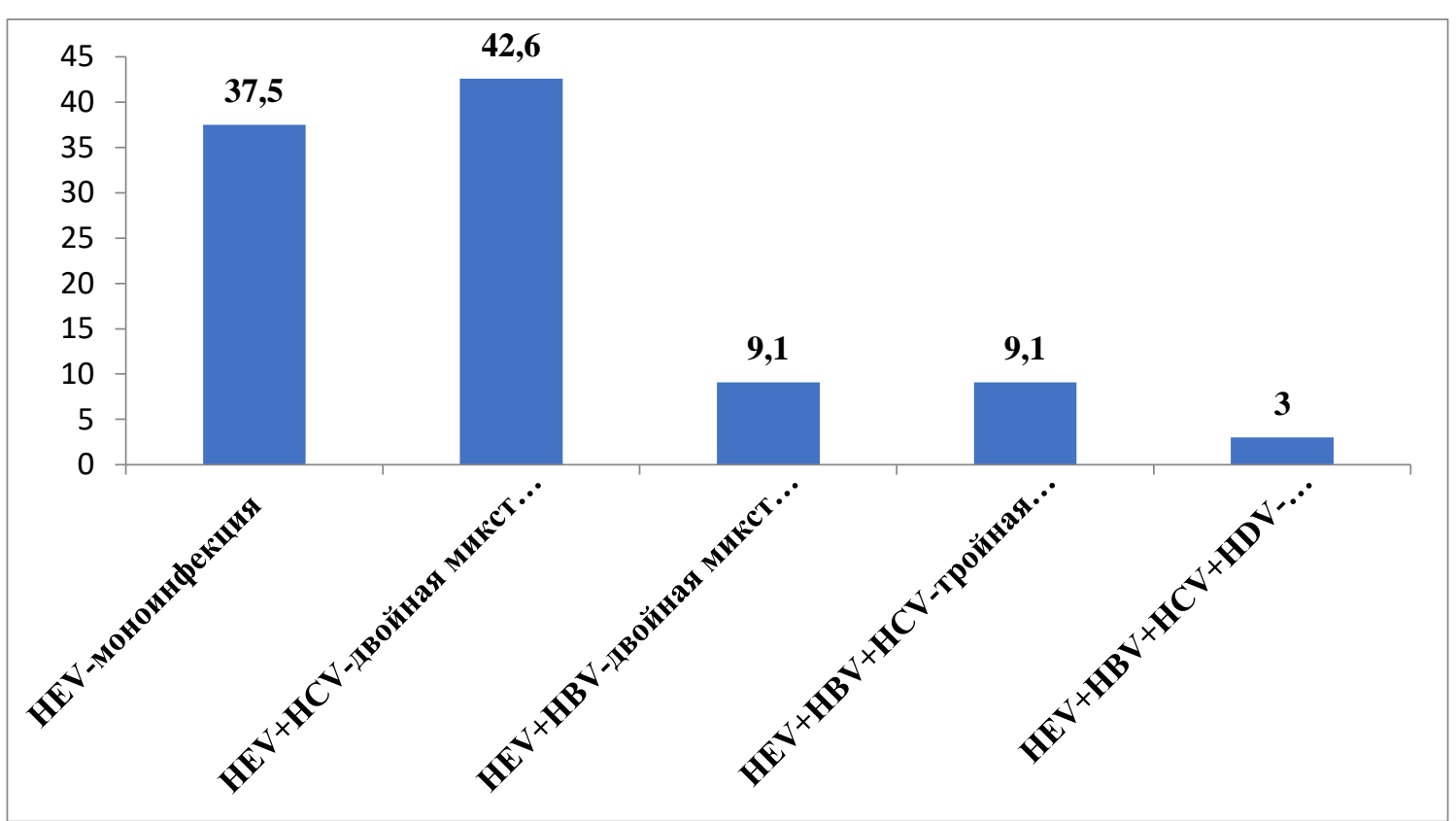

Рисунок 3. Комбинация вируса гепатита Е с несколькими вирусами парентеральньх гепатитов, показатели в \%.

Такая обширная ассоциация вируса $\mathrm{E}$ c парентеральными вирусами С и В возможно связана с высокой степенью иммунодепрессивной активности вирусов гепатита B, C и D. Причем описание случаев острой коинфекции в литературе не встречается. В наших исследованиях не удалось выявить влияние вируса гепатита Е на течение хронического гепатита, вызванного другими вирусами парентеральных гепатитов. Это касается как клинической картины заболевания, так и лабораторных параметров.

Серологическая и молекулярно-биологическая характеристика хронического гепатита В и С в республике отличается повышенной репликативной активностью вирусов более, чем у 3/4 больных и с высокой степенью заражения 2-мя, 3-мя и даже 4-мя другими вирусами гепатита (mixtинфекция). Так среди 19 больных с хроническим гепатитом В маркеры гепатита С встречались 31,5 \% случаев, при этом вирус (РНК HCV) обнаруживался в 21,0\% случаев. Анти HEV IgG выявлены у 21,0\% (4 из 19). Похожая ситуация складывается у больных хроническим вирусным гепатитом С. Среди 68 больных хроническим гепатитом С часто выявляются маркеры гепатита В (HBsAg), гепатита D, гепатита E (по сути, четырехкратная инфекция $(\mathrm{HCV}+\mathrm{HBV}+\mathrm{HDV}+\mathrm{HEV})$ в $11,7 \%, \quad 4,4 \%$ и $25 \%$ случаев соответственно. Причем маркеры вируса гепатита Е встречались намного чаще в $25 \%$ случаев, чем маркеры вируса гепатитов В и С (таблица 9).

\section{ЧЕТЫРЕХКРАТНАЯ ИНФЕКЦИЯ (HВV+HCV+HDV+HЕV) СРЕДИ БОЛЬНЫХ С ХРОНИЧЕСКИМ ГЕПАТИТОМ В (N-19) И С (N-68), ПОКАЗАТЕЛИ В \%}

\begin{tabular}{|l|c|c|c|c|c|c|c|c|}
\hline \multicolumn{1}{|c|}{ Больные } & HBsAg & $\begin{array}{c}\text { a-HBcor } \\
\text { сумм }\end{array}$ & $\begin{array}{c}\text { a-HBe } \\
\text { IgG }\end{array}$ & $\begin{array}{c}\text { ДHK } \\
\text { HBV }\end{array}$ & a-HDV & a-HCV & $\begin{array}{c}\text { PHK } \\
\text { HCV }\end{array}$ & $\begin{array}{c}\text { a-HEV } \\
\text { IgG }\end{array}$ \\
\hline $\begin{array}{l}\text { Скотоведческие } \\
\text { районы (n-64) }\end{array}$ & & & & & & & & 21,8 \\
\hline $\begin{array}{l}\text { Оленеводческий } \\
\text { район (n-12) }\end{array}$ & & & & & & & & 16,6 \\
\hline $\begin{array}{l}\text { Больные с } \\
\text { гепатитом В (n- } \\
\text { 19) }\end{array}$ & 84,2 & 100,0 & 68,4 & 57,8 & 1,4 & 31,5 & 21,0 & 21,0 \\
\hline $\begin{array}{l}\text { Больные с } \\
\text { гепатитом С (n- } \\
\text { 68) }\end{array}$ & 11,7 & 45,5 & 35,3 & 7,3 & 4,4 & 97,0 & 57,3 & 25,0 \\
\hline
\end{tabular}

В заключении можно констатировать, что по результатам серологических, молекулярнобиологических исследований выявлена высокая) заболеваемость и инфицированность населения республики всеми известными вирусами гепатита. Также обнаружена повышенная циркуляция в арктической зоне России такого вируса гепатита как Е, ранее считавшегося тропической инфекцией. Дальнейшее изучение данной проблемы позволило бы определение степени инфицированности населения известными и редко встречающимися вирусами гепатитов и их биологической опасности для популяции. 
Работа выполнена при поддержке гранта РФФИ №18-415-140005 p_a.

\section{СПИСОК ИСТОЧНИКОВ}

ИСПОЛЬЗОВАННЫХ

1. Khuroo M.S. Hepatitis E: an emerging global disease - from discovery towards control and cure / M.S. Khuroo //J Viral Hepat. 2015 Sep 6.

2.Epidemiology of Hepatitis E Virus in European Countries /D. Lapa, M.R. Capobianchi, A.P. Garbuglia [et al.] //Int J Mol Sci. 2015 Oct 27;16 (10):25711-43.

3. Hepatitis $E$ virus antibody prevalence in hunters from a district in Central Germany, 2013: a crosssectional study providing evidence for the benefit of protective gloves during disemboweling of wild boars / A.Schielke, V. Ibrahim, I. Czogiel [et al.] //BMC Infect Dis.2015 Oct 22;15:440.

4.Кузин С.Н. Оценка заболеваемости и этиологической структуры острых и хронических вирусных гепатитов на территории Республики Саха (Якутия).//С.Н. Кузин Вопросы вирусологии. - 2004. - т.49. - №1. - c.20-23.

5.Михайлов М.И., Шахгильдян И.В., Онищенко Г.Г. Энтеральные вирусные гепатиты (этиология, эпидемиология, диагностика, профилактика). - М.:ВУНМЦ Росздрава, 2007. C.134.

6.Солонин С.А. Циркуляция вирусного гепатита Е среди свиней на территории Российской Федерации: Автореф.дис. ... канд.мед.наук. - М., 2010. - C.18.

7. Genotype-4 hepatitis $\mathrm{E}$ in a human after ingesting roe deer meat in South Korea / J.Y. Choi, J.M.
Lee, Y.W. Jo [et al.] //Clin Mol Hepatol. 2013 Sep; 19(3):309-14.

8. Perez-Garcia M.T. Modern knowledge about hepatitis E / M.T Perez-Garcia, B.Suay, M.L.MateosLindemann // Int. J Mol. Sci..2015 Oct; 16 (10): 2571143.

9. Dalton H.R. Hepatitis E in developed countries: current status and future perspectives / H.R. Dalton, N. Kamar, J. Izopet // Future Microbiol. 2014; 9(12):136172.

10. Hepatitis E like virus found in Swedish moose / J. Lin, H. Norder, H. Uhlhorn [et al.] // J Gen Virol. 2014 Mar; 95 (Pt 3):557-70.

11. Cross-species infections of cultured cells by hepatitis $\mathrm{E}$ virus and discovery of an infectious virushost recombinant. // P. Shukla, H.T. Nguyen, U. Torian [et al.] /Proc Natl Acad Sci US A. 2011 Feb 8; 108(6):2438-43.

12. Hepatitis $\mathrm{E}$ virus infection among domestic animals in eastern China. Zoonoses / W. Zhang, Q. Shen, J. Mou [et al.] // Public Health. 2008 Aug; 55(6):291-8.

13. Detection and molecular characterization of hepatitis E virus in clinical, environmental and putative animal sources. / S. Ishida, S. Yoshizumi, T. Ikeda, [et al.] //Arch Virol. 2012 Dec;157(12):2363-8.

14. Baumann-Popczyk A. Hepatitis E as zoonosis. /A. Baumann-Popczyk //Przegl Epidemiol. 2011;65(1):9-13.

15. Hepatitis E. / G. Scotto, F. Bulla, F. Campanale, [et al.] //Infez Med. 2013 Sep;21(3):175-88. 